\title{
Measuring nitrogen and sulphur deposition in the Georgia Basin, British Columbia, using lichens and moss
}

\author{
Beverley A. RAYMOND†ं, Tasha BASSINGTHWAIGHTE and D. Patrick SHAW* \\ Environment Canada, 201-401 Burrard Street, Vancouver, BC V6C 3S5, Canada \\ $\uparrow$ Deceased \\ *e-mail corresponding author: pat.shaw@ec.gc.ca
}

\begin{abstract}
Nitrogen $(N)$ and sulphur $(S)$ in the lichens Platismatia glauca, Parmelia sulcata and Hypogymnia physodes and a moss, Isothecium myosuroides in southwestern British Columbia was studied in a two component program. Firstly, relationships between lichen and moss tissue chemistry and atmospheric loading were explored using data collected at four regional air and precipitation chemistry monitoring sites in an effort to develop predictive models to estimate deposition. Secondly, the regional pattern of atmospheric $N$ and $S$ deposition was studied in a survey of lichen and moss tissue chemistry at fifty-seven locations in the Georgia Basin area. Results of the tissue chemistry was then compared to 1) modelled $N$ and $S$ deposition estimates and 2) lichen community structure response thresholds for $N$. The calibration component of this study was not successful owing to generally weak relationships between measured deposition and tissue $N$ and $S$. Additional effort will be needed to define a functional relationship between $N$ or $S$ loading and tissue content. Correlations between the lichen and moss $N$ content and model predictions were generally good. Correspondence between modelled $S$ deposition and tissue content were more variable, but quite good for the dry $S$ component. Nitrogen levels in lichen tissues suggest that lichen communities are probably being affected in urban areas and eastward into the Fraser Valley.
\end{abstract}

Key words: biomonitoring, nitrogen deposition, sulphur deposition, Canada

\section{INTRODUCTION}

The potentially damaging effects of atmospheric sulphur (S) and nitrogen $(\mathrm{N})$ deposition to both terrestrial and aquatic ecosystems have long been known. Acidification due to industrial S emissions have been a great concern in eastern Canada, where ongoing initiatives have led to development of critical loads for $\mathrm{S}$ deposition (Holdren et al. 1993; Jeffries et al. 1999). While coastal British Columbia is not burdened with high industrial $\mathrm{S}$ emissions of eastern Canada, the area is particularly vulnerable to acidification due to highly resistant and acidic bedrock geology, which greatly limit potential buffering of incoming acid deposition (Wiens 1987). There has been increasing concern worldwide about the effects of excess $\mathrm{N}$ in the environment (Matson et al. 2002; Fenn et al. 2003; Galloway et al. 2003; Krupa 2003; Bergström \& Jansson 2006; Pitcairn et al. 2006). In sensitive ecosystems, $\mathrm{N}$ deposition thresholds associated with effects on both terrestrial plant (species shifts) and aquatic communities (species shifts, eutrophication) may be very low (Rabalais 2002; Fenn et al. 2003; Baron 2006; Porter \& Johnson 2007).

Air quality in south-western British Columbia is affected by intensive urban and agricultural development both within Canada and from adjacent Washington State. The Vancouver and Fraser Valley Region hosts a population (2005) of about 2.6 million (MetroVancouver 2007) which is expected to more than double in the next 20 years. Intense agricultural activity in the Lower
Fraser Valley to the east of Vancouver generates high levels of ammonia $\left(\mathrm{NH}_{3}\right)$, which combined with sulphur dioxide $\left(\mathrm{SO}_{2}\right)$ and nitrogen oxide $\left(\mathrm{NO}_{\mathrm{x}}\right)$ emissions related to urban activities result in episodes of poor regional air quality (Vingarzan \& Li 2006). In addition, $\mathrm{S}$ emissions from marine traffic to the port of Vancouver is an important and growing source of both $\mathrm{NO}_{\mathrm{x}}$ and $\mathrm{SO}_{2}$ (MetroVancouver 2007).

MetroVancouver (previously Greater Vancouver Regional District) and the British Columbia Ministry of Environment (BCMOE) operate an extensive regional air quality monitoring network. Sites are located in urban, industrial, and agricultural areas, and most locations monitor only particulate and gaseous pollutant levels-particulate matter $\left(\mathrm{PM}_{2.5}\right.$ and/or $\left.\mathrm{PM}_{10}\right)$. $\mathrm{NO}_{\mathrm{x}}, \mathrm{SO}_{2}$, and ground-level ozone $\left(\mathrm{O}_{3}\right)$ (MetroVancouver 2008). With recent development of depositional critical loads for soils and for $\mathrm{N}$ and $\mathrm{S}$ for southwestern BC (see Nasr et al. 2010, this issue) there is a growing need for empirical loading estimates with which to assess exceedences and highlight areas for management actions. BCMOE over the period 1983 to 2007 conducted rain chemistry monitoring at up to 14 locations, but all have been discontinued (Warren McCormick, BC Environment, personal communication). Presently, rainfall chemistry is measured at the single Canadian Acid Precipitation Monitoring Network (CAPMoN) site on Saturna Island in the southern Strait of Georgia.

Use of lichens and mosses in atmospheric biomonitoring has a long and extensive history, particularly in 


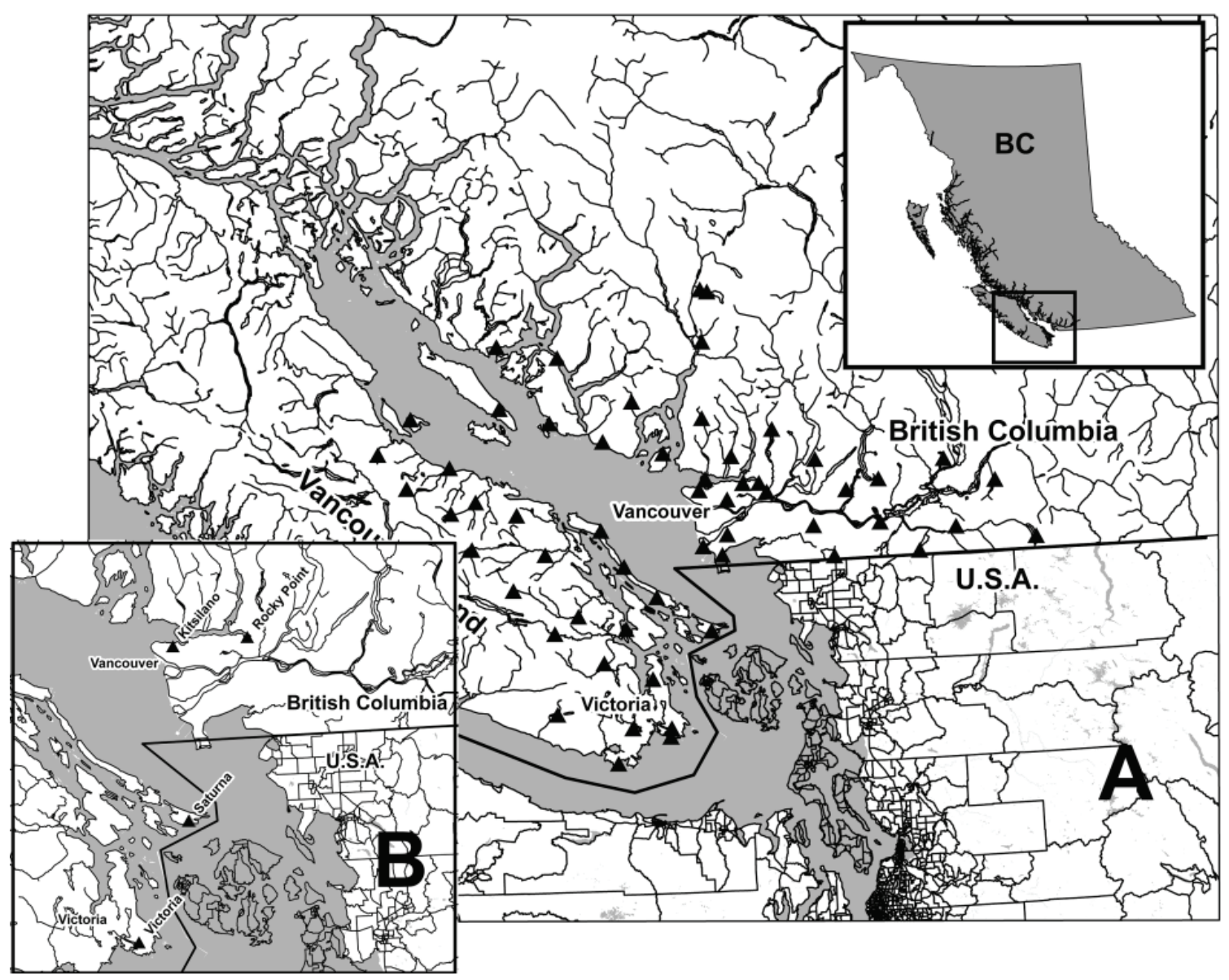

Fig. 1. Location of (A) lichen sampling and (B) precipitation chemistry monitoring sites in southwestern British Columbia.

Europe. Moss was first used as an indicator of heavy metal pollution in Sweden in the late 1960s (Ruhling \& Tyler 1969). A standardized method has evolved that is widely used in air pollution monitoring throughout Europe (Berg \& Steinnes 1997b; Ceburnis et al. 1999; Holoubek et al. 2000; Conti \& Cecchetti 2001; Fernández et al. 2007). In the Pacific Northwest states, the United States Forest service has been using mosses and lichens to monitor N, S and metals deposition to National Forests and Parks since 1993, with considerable success (Geiser 2004; Geiser \& Neitlich 2007). This work has lead to extensive data sets (http://gis.nacse.org/lichenair/index.php) and protocols for collection, analysis and interpretation of both lichen chemistry and lichen species (Geiser 2004). Within the Georgia Basin, metal deposition was investigated using a moss species in 1960-63, 1975-1980, and 1993 in the Lower Fraser Valley (Pott \& Turpin 1996; Pott \& Turpin 1998). Significant and strong relationships have been established between deposition and moss for levels of N, S, metals, and PAHs (Berg \& Steinnes 1997a; Geiser 2004). Recently, the utility of tissue chemistry measurement has been extended to development of 'lichen-based' critical loads based on analyses of lichen species community structure (Glavich \& Geiser 2008).
The present work set about testing the utility of lichen and moss chemistry to obtain a more complete spatial pattern of air quality and atmospheric $\mathrm{N}$ and $\mathrm{S}$ deposition throughout the Georgia Basin. A second objective of this study involved defining relationships between measured $\mathrm{N}$ and $\mathrm{S}$ deposition in rainfall with content in moss and lichens so that measured tissue chemistry might be translated to approximate loading estimates.

\section{METHODS}

\subsection{Study area}

The Strait of Georgia is located in the southwest corner of British Columbia in western Canada (Fig. 1). This is an area of complex topography, including the coastal mountain range and many fjords which influence the level of precipitation, temperature, and local wind patterns. In general, the climate is characterized by cool dry summers and mild wet winters. Regional air quality is affected by stagnation episodes during which sea-breeze associated westerly flows from the Pacific Ocean drive urban and marine emissions into the Fraser Valley east of Vancouver. Communities on the margins of the Strait of Georgia contribute to $\mathrm{N}$ and $\mathrm{S}$ loadings 
to the airshed as do occasional southerly flows from the large population and industrial centers in western Washington State (Seattle, Tacoma and Whatcom County).

\subsection{Sampling design and biomonitoring species}

Lichen and moss tissues were collected at fiftyseven sampling areas on a $20 \mathrm{~km} \times 20 \mathrm{~km}$ grid over the Georgia Basin ('Grid Sites': Fig. 1a) and at one rural and three urban rain chemistry locations ('Calibration Sites': Fig. 1b) To provide some flexibility in sampling locations, four species were used in this study. Priority was given to the collection of the lichen Platismatia glauca and the moss Isothecium myosuroides, but where these species were not found, the lichens Hypogymnia physodes or Parmelia sulcata were collected.

Isothecium myosuroides Bridel (syn. I. stoloniferum) is a pleurocarpous moss in the family Brachytheciaceae (i.e. a 'feather moss') common in humid forests in Western North America (Ireland et al. 1987). It is extremely variable morphologically, ranging from much-branched to regular, dark green to golden brown-green (Schofield 1992). This species has been used for biomonitoring in southwestern British Columbia (Raymond \& Pott 2003). Platismatia glauca (L.) is a large foliose epiphytic lichen common in spruce and Douglas-fir forests (Brodo et al. 2001). It is easily identified, pollution-tolerant and is among the most common lichen species in forested areas of the Georgia Basin, and is the preferred biomonitoring species in Washington and Oregon (Geiser 2004; Geiser \& Neitlich 2007). Hypogymnia physodes (L.) and Parmelia sulcata Taylor are widespread, pollution-tolerant and easily identified foliose epiphytic lichens (Brodo et al. 2001). Both have widespread application in atmospheric biomonitoring, and H. physodes is perhaps the most widely used species of lichen biomonitor in the world (Pfeiffer \& Barclay-Estrup 1992; Rhoades 1999).

\subsection{Sampling protocol for lichen and moss}

Samples were collected from tree trunks, branches, shrubs and logs at least $1 \mathrm{~m}$ above ground, and from a minimum of six locations at each site. Samples were collected at least $200 \mathrm{~m}$ from minor roads, $500 \mathrm{~m}$ from highways, and a few metres from forest trails. At the three urban calibration sites (i.e. Kitsilano, Rocky Point, and Topaz-Victoria) samples were collected from trees along residential streets or in urban parks. Clean, green shoots were cut from moss with scissors directly into pre-cleaned polyethylene jars. Live lichen tissue was cut from the bark of trees with clean stainless steel tools directly into pre-cleaned polyethylene jars. Collections were air-dried as soon as possible by spreading onto clean herbarium paper in a clean area and returned to jars. As a final step before submitting to the analytical laboratory, species determinations were confirmed and samples were cleaned of dead tissue and debris.
Quality assurance procedures included field replicates or field splits and submission of standard reference materials [CRM482 (lichen) and NIST CRM1547 (peach leaves)].

\subsection{Chemical analyses}

Sulphur and $\mathrm{N}$ analyses in tissue were conducted at the University of Minnesota Research Analytical Laboratory (UMRAL), St. Paul, MN. Air-dried samples ground to pass a 20 -mesh sieve and dried at $65^{\circ} \mathrm{C}$ for 2 hours before transfer to a desiccator. Total $\mathrm{S}$ was determined using a Leco Corp SC-132 Sulphur Analyzer. Total Kjedahl N in plant tissue was determined spectrophotometrically on a Technicon ${ }^{\circledR}$ AutoAnalyzer after digestion in sulphuric acid. Total $\mathrm{N}$ was measured using a LECO FP-528 Nitrogen Analyzer.

\subsection{Air and precipitation chemistry}

Rain samples were collected using a M.I.C. Co. (Thornhill, Ontario) precipitation collector equipped with a bucket lined with a standard Canadian Acid Precipitation Monitoring Network (CAPMoN) polyethylene/mylar laminate bag (Sirois \& Vet 1999). The bucket was taken out of the precipitation collector weekly, the bag inside the bucket sealed and shipped to the analytical laboratory. A new bucket with a clean bag was then installed to ensure continuous precipitation collection. The gasket in the hood of the precipitation sampler was changed monthly to ensure a good seal during dry periods, except at the Saturna Island site where the gasket was changed biweekly to prevent contamination from sea salt.

Quality assurance included field blanks, which were prepared during sample periods with no rainfall. A 500 $\mathrm{mL}$ volume of trace element-clean deionised water was poured into the sampling bag and processed as normal. Monthly field splits of the rainwater sample were used to estimate precision of the sample preparation and analyses.

Analyses were conducted at the Environment Canada Pacific Environmental Science Centre (PESC) in North Vancouver, BC. Samples were settled and aliquots were decanted through $0.45 \mu \mathrm{m}$ Sartorius acetate membrane filters on arrival at the laboratory, then stored at $4{ }^{\circ} \mathrm{C}$ until analysis. Cations $\left(\mathrm{Na}^{+}, \mathrm{K}^{+}, \mathrm{Mg}^{2+}, \mathrm{Ca}^{2+}\right.$, $\mathrm{NH}_{4}{ }^{+}$) were analyzed by autosuppressed ion chromatography/conductivity detection using a Dionex-DX 500 Chromatograph and ED40 Conductivity Detector within 14 days of arriving at the laboratory. Anions $\mathrm{Cl}^{-}$, $\mathrm{NO}_{3}{ }^{-}, \mathrm{SO}_{4}{ }^{2-}$ ) were analyzed by chemically suppressed ion chromatography/conductivity detection using a Dionex-DX 500 Chromatograph and ED20 conductivity detector within 5 days of arrival at the laboratory.

For quality assurance, method blanks were included in each analytical run. Method accuracy was determined by adding a known amount of a particular constituent and recovery was measured. Method precision was 
Tab. 1. Summary of precipitation chemistry (ammonium, nitrate and sulphate) at calibration sites in Vancouver, Victoria and Saturna Island. Concentrations are not volume-weighted.

\begin{tabular}{|c|c|c|c|c|c|c|c|c|c|c|c|}
\hline \multirow[t]{2}{*}{ Location } & \multirow[t]{2}{*}{$\mathrm{N}$} & \multicolumn{3}{|c|}{$\mathrm{NH}_{4}\left(\mathrm{mg} \mathrm{L}^{-1}\right)$} & \multicolumn{3}{|c|}{$\mathrm{NO}_{3}^{-}\left(\mathrm{mg} \mathrm{L}^{-1}\right)$} & \multicolumn{3}{|c|}{$\mathrm{SO}_{4}{ }^{2-}\left(\mathrm{mg} \mathrm{L}^{-1}\right)$} & \multirow{2}{*}{$\begin{array}{l}\text { Precip. } \\
\text { (cm) }\end{array}$} \\
\hline & & Mean & SD & Range & Mean & SD & Range & Mean & $\mathrm{SD}$ & Range & \\
\hline Kitsilano & $37-41$ & 0.27 & 0.2 & $0.01-1.15$ & 0.98 & 0.75 & $0.03-3.96$ & 1.13 & 0.76 & $0.02-3.79$ & 103 \\
\hline Rocky Point & $40-42$ & 0.28 & 0.2 & $0.01-1.33$ & 1.00 & 0.90 & $0.01-5.72$ & 1.01 & 0.78 & $0.02-4.01$ & 140 \\
\hline Victoria & $33-35$ & 0.15 & 0.2 & $0.01-0.60$ & 0.70 & 0.93 & $0.03-5.42$ & 0.99 & 0.66 & $0.09-3.33$ & 57 \\
\hline Saturna & $33-39$ & 0.16 & 0.2 & $0.01-0.82$ & 0.98 & 0.88 & $0.01-4.82$ & 0.97 & 0.71 & $0.08-4.47$ & 70 \\
\hline
\end{tabular}

tested by seven replicate determinations at three different concentrations.

\subsection{Dry deposition estimates}

Dry deposition estimates for the sites were calculated by Hay et al. (2005). Briefly, dry deposition velocities were computed at three hour intervals using the Environment Canada Air Quality Research Branch Regional Deposition Model (RDM) and modelled surface temperatures (Zhang \& Brook 2001; Zhang et al. 2003). Computed daily average deposition velocities were used to calculate annual total deposition.

\subsection{Atmospheric deposition modelling}

Tissue chemistry results were compared to predicted deposition generated by the EPA Community Multiscale Air Quality model (CMAQ) The model was run daily for a two year period (2004-2006) at the University of British Columbia for a domain including much of southwestern British Columbia at a $4 \mathrm{~km}$ grid resolution using MC2 meteorology (Benoit et al. 1997). From the archived model output, $\mathrm{N}$ and $\mathrm{S}$ components were summed and averaged to provide mean annual estimates. The final datasets were kriged using ArcGIS Geostatistical Analyst extension, and point $\mathrm{N}$ and $\mathrm{S}$ deposition estimates extracted from the resulting modelled surface.

\subsection{Statistical analysis}

Least-squares regressions and ANOVA were used to model relationships between $\mathrm{N}$ and $\mathrm{S}$ species content and the measured and modelled wet/dry/total deposition. Statistical analyses were carried out using SYSTAT 10 with subsequent graphical analyses using SigmaPlot 10.

\section{RESULTS}

\subsection{Tissue chemistry and precipitation calibration}

A full year of weekly chemistry data were collected from the four monitoring sites representing a gradient of environments from highly urban (Kitsilano) to rural (Saturna). Average rainwater nitrate $\left(\mathrm{NO}_{3}{ }^{-}\right)$and sulphate $\left(\mathrm{SO}_{4}{ }^{2-}\right)$ concentrations at the four sites were similar, but ammonium $\left(\mathrm{NH}_{4}{ }^{+}\right)$at the two Vancouver sites were twice $(0.15$ vs 0.28$)$ that of the remaining locations (Tab. 1). Air quality data (courtesy of GVRD and CAPMon) for the period of precipitation chemistry monitoring are summarized in table 2 .
Calculated annual $\mathrm{N}$ and $\mathrm{S}$ deposition loads are summarized in table 3 . Total $\mathrm{N}$ loadings (approximately $\left.8.5 \mathrm{~kg} \mathrm{ha}^{-1} \mathrm{y}^{-1}\right)$ were highest in the vicinity of Vancouver (Kitsilano and Rocky Point), with about equal contributions of dry and wet deposition. It was only in Victoria where the wet deposition fell to just $25 \%$ of the total. Sulphate loading ranged from about $3 \mathrm{~kg} \mathrm{ha}^{-1} \mathrm{y}^{-1}$ on Saturna Island to $6.5 \mathrm{~kg} \mathrm{ha}^{-1} \mathrm{y}^{-1}$ at Rocky Point, a location downwind of most of MetroVancouver and which receives about $50 \%$ more precipitation than the Kitsilano site.

Tab. 2. Mean annual air concentrations $\left(\mu \mathrm{g} \mathrm{m}^{-3}\right)$ of particles and gasses at the four calibration sites used in dry deposition loading estimates. Data courtesy Greater Vancouver Regional District (now MetroVancouver) and CAPMoN.

\begin{tabular}{lcccccc}
\hline Location & $\mathrm{NH}_{4}^{+}$ & $\mathrm{NO}_{2}$ & $\mathrm{NO}_{3}{ }^{-}$ & $\mathrm{S}$ & $\mathrm{SO}_{2}$ & $\mathrm{SO}_{4}{ }^{2-}$ \\
\hline Kitsilano & 0.39 & 38.5 & 0.588 & 0.42 & 5.54 & 1.31 \\
Rocky Point & 0.42 & 31.1 & 0.490 & 0.44 & 5.56 & 1.28 \\
Victoria & 0.30 & 19.9 & 0.526 & 0.38 & 3.01 & 1.02 \\
Saturna & 0.36 & n/a & 0.886 & n/a & 1.73 & 1.02 \\
\hline
\end{tabular}

Tab. 3. Calculated nitrogen and sulphur loading (kg $\mathrm{ha}^{-1} \mathrm{y}^{-1}$ ) at the four precipitation chemistry sites monitored in this study. Dry deposition estimates from Hay et al. (2005).

\begin{tabular}{|c|c|c|c|c|c|}
\hline & & Kitsilano & Rocky Point & Victoria & Saturna \\
\hline \multirow{3}{*}{ Nitrogen } & Dry & 4.77 & 4.12 & 3.82 & 1.08 \\
\hline & Wet & 3.73 & 4.47 & 1.00 & 1.56 \\
\hline & Total & 8.50 & 8.59 & 4.82 & 2.64 \\
\hline \multirow{3}{*}{ Sulphur } & Dry & 2.10 & 2.66 & 1.69 & 1.59 \\
\hline & Wet & 3.49 & 3.88 & 1.58 & 1.38 \\
\hline & Total & 5.59 & 6.54 & 3.27 & 2.97 \\
\hline
\end{tabular}

All four species of lichens were collected at each of the precipitation chemistry sites, but I. myosuroides was not present at the Victoria location. Lichen and moss tissue $\mathrm{N}$ and $\mathrm{S}$ content at the four rain and air chemistry sites showed a range within a particular species. Relationships between nitrogen and sulphur loading and tissue chemistry were variable and generally quite poor (Tab. 4). While most of the linear regressions were not statistically significant, all three lichen species showed good relationships between tissue $\mathrm{N}$ and dry $\mathrm{N}$ deposition. Only in I. myosuroides was there a relationship between measured $\mathrm{S}$ deposition and tissue $\mathrm{S}$ content.

Interspecies relationships in $\mathrm{N}$ and $\mathrm{S}$ content were excellent, with $r^{2}$ values between $P$. glauca and the other 3 species ranging from 0.91-0.98. Regression parameters for these relationships are presented in table 5 . 
Tab. 4. Least-squares regression statistics for tissue chemistry-loading calibration. Coefficients refer to the relationship: $\%$ nitrogen or $\%$ sulphur $=\mathrm{a}+\mathrm{x} \times$ nitrogen or sulphur loading $\left(\mathrm{kg} \mathrm{ha}^{-1} \mathrm{y}^{-1}\right) . \operatorname{SE}(\mathrm{a})$ and $\mathrm{SE}(\mathrm{x})$ are standard errors for the calculated regression parameters. ${ }^{1)}$ : Isothecium myosuroides was not present in the Victoria site.

\begin{tabular}{|c|c|c|c|c|c|c|c|c|c|}
\hline Species & Element & Form & $\mathrm{n}$ & $\mathrm{a}$ & $\mathrm{SE}(\mathrm{a})$ & $\mathrm{x}$ & $\mathrm{SE}(\mathrm{x})$ & $r^{2}$ & $p$ \\
\hline \multirow{6}{*}{ P. glauca } & \multirow{3}{*}{ Nitrogen } & dry & 24 & 0.624 & 0.11 & 0.224 & 0.04 & 0.60 & $<0.001$ \\
\hline & & wet & 24 & 1.248 & 0.18 & 0.047 & 0.06 & 0.03 & 0.433 \\
\hline & & total & 43 & 0.893 & 0.19 & 0.085 & 0.03 & 0.28 & 0.008 \\
\hline & \multirow{3}{*}{ Sulphur } & dry & 43 & 0.132 & 0.04 & 0.018 & 0.02 & 0.03 & 0.311 \\
\hline & & wet & 43 & 0.140 & 0.02 & 0.011 & 0.01 & 0.07 & 0.089 \\
\hline & & total & 43 & 0.135 & 0.02 & 0.007 & 0.01 & 0.06 & 0.124 \\
\hline \multirow{6}{*}{ P. sulcata } & \multirow{3}{*}{ Nitrogen } & dry & 23 & 1.097 & 0.13 & 0.101 & 0.03 & 0.30 & 0.007 \\
\hline & & wet & 23 & 1.487 & 0.12 & -0.018 & 0.04 & 0.01 & 0.667 \\
\hline & & total & 23 & 1.280 & 0.15 & 0.027 & 0.07 & 0.07 & 0.240 \\
\hline & \multirow{3}{*}{ Sulphur } & dry & 43 & 0.134 & 0.02 & 0.005 & 0.01 & 0.01 & 0.612 \\
\hline & & wet & 43 & 0.135 & 0.01 & 0.004 & 0.00 & 0.03 & 0.255 \\
\hline & & total & 43 & 0.133 & 0.01 & 0.003 & 0.00 & 0.02 & 0.321 \\
\hline \multirow{6}{*}{ H. physodes } & \multirow{3}{*}{ Nitrogen } & dry & 21 & 0.884 & 0.13 & 0.128 & 0.04 & 0.39 & 0.002 \\
\hline & & wet & 21 & 1.341 & 0.14 & -0.011 & 0.05 & 0.00 & 0.834 \\
\hline & & total & 21 & 1.074 & 0.16 & 0.041 & 0.03 & 0.12 & 0.127 \\
\hline & \multirow{3}{*}{ Sulphur } & dry & 40 & 0.128 & 0.03 & 0.018 & 0.01 & 0.04 & 0.220 \\
\hline & & wet & 40 & 0.147 & 0.01 & 0.006 & 0.01 & 0.04 & 0.213 \\
\hline & & total & 40 & 0.142 & 0.02 & 0.005 & 0.01 & 0.04 & 0.208 \\
\hline \multirow{6}{*}{ I. myosuroides $^{1)}$} & \multirow{3}{*}{ Nitrogen } & dry & 16 & 1.524 & 0.13 & 0.063 & 0.04 & 0.17 & 0.114 \\
\hline & & wet & 16 & 1.629 & 0.18 & 0.030 & 0.05 & 0.02 & 0.574 \\
\hline & & total & 16 & 1.554 & 0.16 & 0.027 & 0.02 & 0.09 & 0.253 \\
\hline & \multirow{3}{*}{ Sulphur } & dry & 30 & 0.104 & 0.02 & 0.012 & 0.01 & 0.08 & 0.139 \\
\hline & & wet & 30 & 0.104 & 0.01 & 0.009 & 0.00 & 0.28 & 0.003 \\
\hline & & total & 30 & 0.101 & 0.01 & 0.006 & 0.00 & 0.22 & 0.009 \\
\hline
\end{tabular}

Tab. 5. Inter-comparison between tissue nitrogen and sulphur in Platismatia glauca and other sampled lichens and mosses. Shown are least-squares linear regression statistics $\left([\mathrm{N} / \mathrm{S}]_{\mathrm{P} \text {. glauca }}=\right.$ $\mathrm{a} \times[\mathrm{N} / \mathrm{S}]_{\text {species b }}$ ) for untransformed data.

\begin{tabular}{l|ccccc}
\hline Species & $\mathrm{n}$ & Variable & $\mathrm{a}$ & $\mathrm{SEa}$ & $r^{2}$ \\
\hline \multirow{2}{*}{ H. physodes } & 28 & Total Nitrogen & 1.168 & 0.033 & 0.97 \\
& 47 & Sulphur & 1.050 & 0.025 & 0.98 \\
P. sulcata & 28 & Total Nitrogen & 0.982 & 0.036 & 0.97 \\
& 45 & Sulphur & 1.152 & 0.033 & 0.96 \\
I. myosuroides & 53 & Total Nitrogen & 0.604 & 0.026 & 0.91 \\
& 64 & Sulphur & 1.064 & 0.034 & 0.94 \\
\hline
\end{tabular}

Tab. 6. Summary of lichen and moss tissue chemistry from sites in southwest British Columbia.

\begin{tabular}{|c|c|c|c|c|c|c|c|c|c|c|}
\hline \multirow[t]{2}{*}{ Species } & \multirow[t]{2}{*}{$\mathrm{N}$} & \multicolumn{3}{|c|}{ Tot. Kjeldahl Nitrogen $(\%)$} & \multicolumn{3}{|c|}{ Total Nitrogen $(\%)$} & \multicolumn{3}{|c|}{ Sulphur (\%) } \\
\hline & & Mean & SD & Range & Mean & $\mathrm{SD}$ & Range & Mean & SD & Range \\
\hline & 45 & & 0.343 & $0.24-1$ & & & & 0.092 & 0.036 & \\
\hline P. sulcata & 10 & 1.346 & 0.318 & $1.10-2$ & 1.354 & 0.431 & $0.57-2$ & 0.186 & 0.134 & $0.11-0.56$ \\
\hline H. physodes & 10 & 0.870 & 0.455 & $0.09-1.44$ & 0.964 & 0.415 & $0.35-1.52$ & 0.133 & 0.056 & $0.05-0.20$ \\
\hline I. myosuroides & 45 & 1.277 & 0.380 & $0.72-2.57$ & 1.350 & 0.396 & $0.72-2.63$ & 0.099 & 0.020 & $0.07-0.16$ \\
\hline
\end{tabular}

\subsection{Tissue chemistry survey}

A total of fifty-seven sites in the vicinity of the Strait of Georgia were sampled for moss and lichen tissue chemistry. Of these locations, $P$. glauca was collected from $56(98 \%), I$. myosuroides from $49(86 \%)$ and $P$. sulcata and $H$. physodes each from $10(17 \%)$ of the 57 collection sites. Most of the subsequent analyses were conducted using only $P$. glauca and I. myosuroides since the intent of the work was to provide information for the widest possible geographic coverage.

The measured tissue $\mathrm{N}$ and $\mathrm{S}$ content in the lichens and mosses from grid locations is summarized in table 6. In $P$. glauca, the only species for which the United States Department of Agriculture (USDA) measured background tissue concentrations (Geiser \& Neitlich 

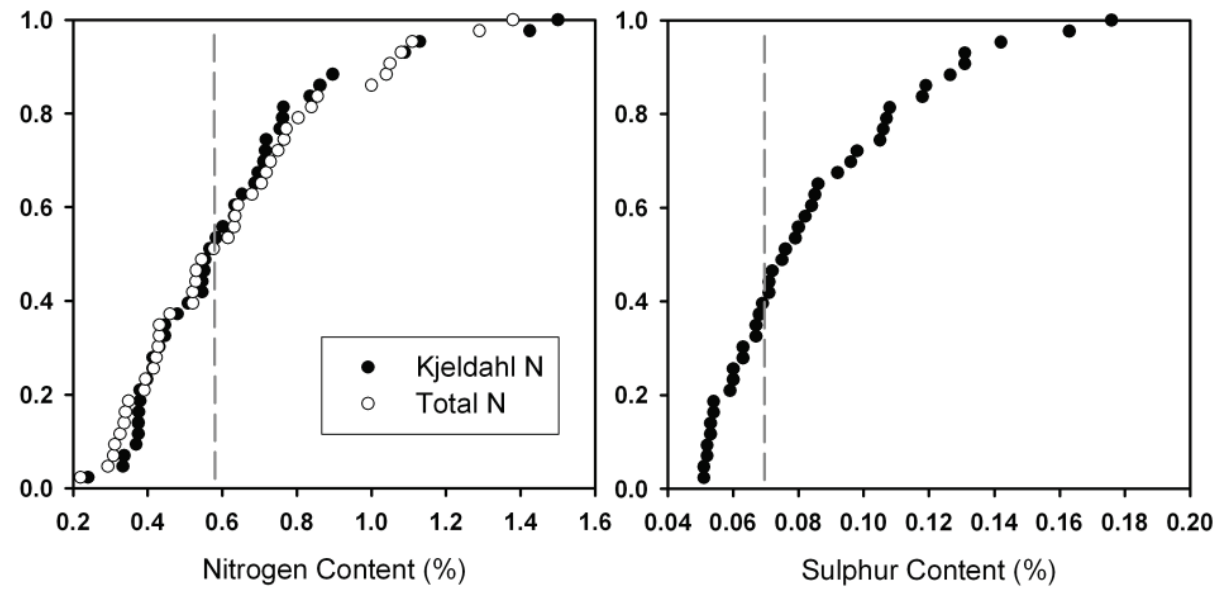

Fig. 2. Distribution of measured tissue nitrogen (N) and sulphur (S) content in Platismatia glauca from southwestern British Columbia. The dashed vertical line in each plot indicates threshold $\mathrm{N}$ and $\mathrm{S}$ levels $(0.59 \% \mathrm{~N}$ and $0.07 \% \mathrm{~S})$ in background 'reference' areas in Oregon, Washington and Alaska as reported by the US Department of Agriculture (URL: gis.nacse.org/lichenair/index.php? page $=$ cleansite).
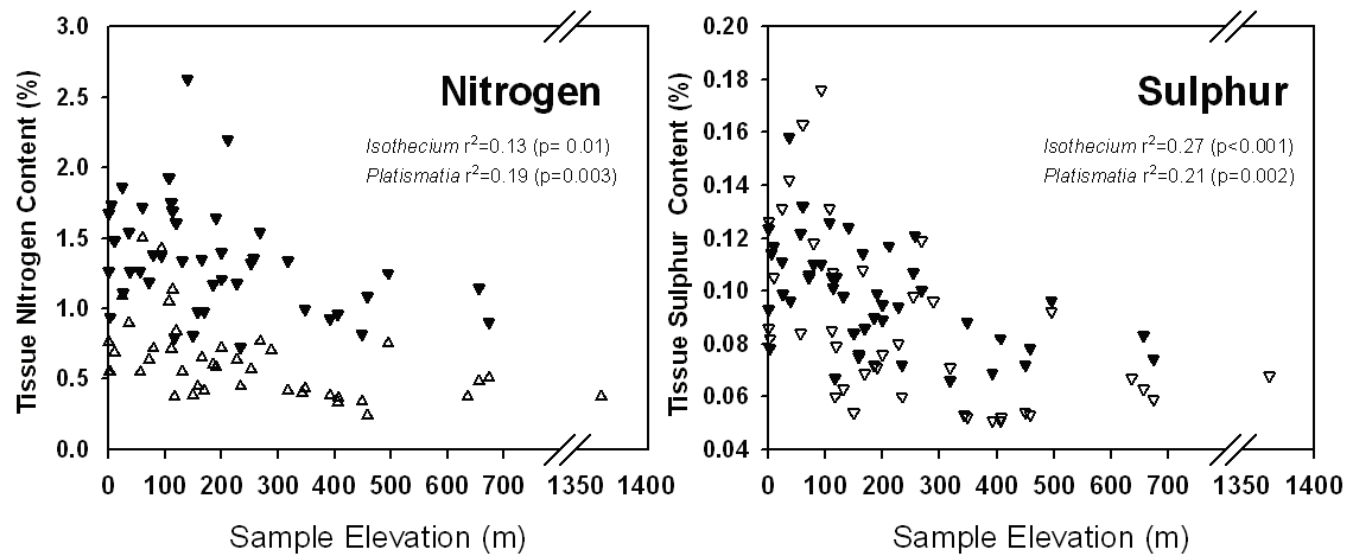

Fig. 3. Relationship between sample site elevation and tissue nitrogen and sulphur content in the moss Isothecium stoloniferum and the lichen Platismatia glauca in SW BC.

2007) were available, the tissue $\mathrm{N}$ content at about $50 \%$ and $\mathrm{S}$ content in about $60 \%$ of the sites were higher than would be expected at 'pristine'sites (Fig. 2). Results of the two analytical methods for $\mathrm{N}$ determination are shown for reference. Despite the high apparent similarity in the two $\mathrm{N}$ distribution by the two techniques (K-S test; $p=0.86$ ), the paired Total and Kjeldahl $\mathrm{N}$ measurements were significantly different (paired sample $t$ test; $p=0.007$ ). This should be a caution in comparing analyses by the two methods, and the subsequent analyses made use of only the total $\mathrm{N}$ dataset.

Tissue $\mathrm{N}$ and $\mathrm{S}$ was highly correlated in both $P$. glauca $\left(r^{2}=0.87\right)$ and moss $\left(r^{2}=0.74\right)$, perhaps a consequence of both elements being predominantly released from combustion sources - where high $\mathrm{N}$ deposition is occurring, so too will $\mathrm{S}$ deposition be expected to be high. Both tissue $\mathrm{N}$ and $\mathrm{S}$ content declined with elevation (Fig. 3), consistent with the concentration of urban, industrial and marine traffic sources at or near sea level with attenuation and dispersion with distance. Further, precipitation tends to increase with elevation diluting deposition concentrations and promoting $\mathrm{N}$ leaching from epiphytes.

The correspondence between tissue chemistry at the grid sample sites and modelled estimates was variable. Correlations between wet, dry and total $\mathrm{N}$ deposition and tissue levels were low, but statistically significant (Fig. 4). The modelled CMAQ dry S deposition was moderately $\left(r^{2}=0.41\right)$ correlated with tissue content of both moss and lichen, but wet deposition was poorly $\left(r^{2}\right.$ $=0.04)$ related to tissue levels. Even although the correlation between tissue chemistry and $\mathrm{S}$ dry deposition is relatively strong, dry S constitutes only an average of $18 \%$ of the total S. As a result, the relationship between modelled total and tissue chemistry is weak (Fig. 4).

The lichen $\mathrm{N}$ response levels from Glavich \& Geiser (2008) were mapped on the survey tissue $\mathrm{N}$ content in $P$. glauca, either directly determined or estimated from relationships (Tab. 5) between $P$. glauca and alternate species in the few instances where this species was not 

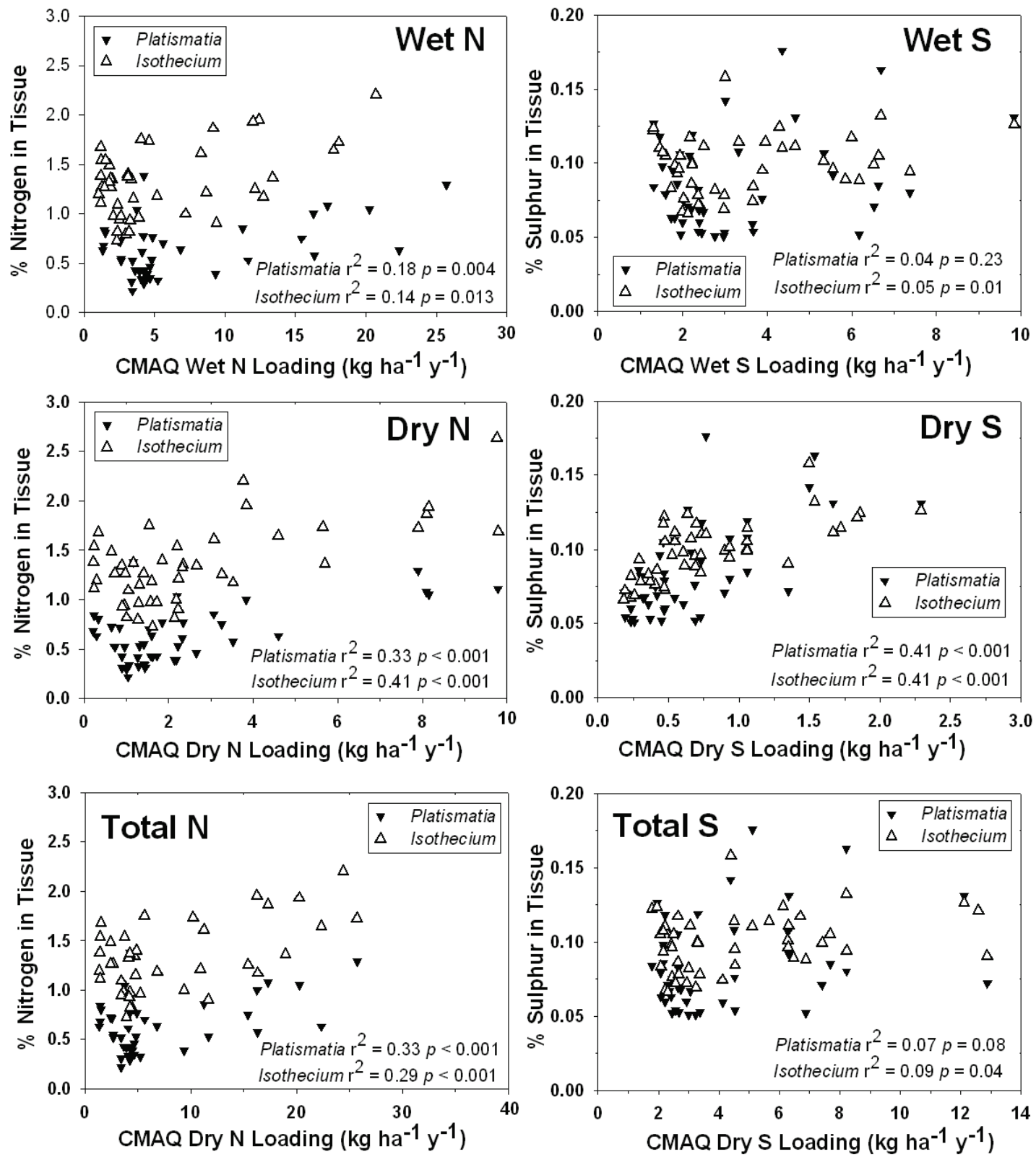

Fig. 4. Relationship between CMAQ modelled $\mathrm{N}$ and $\mathrm{S}$ deposition estimates (wet, dry and total) and tissue chemistry measurements Platismatia glauca and from Isothecium myosuroides.

present. The class intervals and qualitative air quality assessments for tissue $\mathrm{N}$ content were: Good $(\% \mathrm{~N}$ $<0.54 \%)$; Good-Fair $(\% \mathrm{~N}=0.54-0.61 \%)$; Fair $(\% \mathrm{~N}=$ $0.61-0.88 \%)$; and Poor $(\% \mathrm{~N}>0.88 \%)$. When CMAQderived deposition fields were overlaid, there was clear correspondence between areas of high $\mathrm{N}$ loading and locally poor air quality as determined by lichen tissue $\mathrm{N}$ levels (Fig. 5). Lichen-determined air quality was poorest $(\bullet)$ near Vancouver and eastward through the lower Fraser Valley, and graded to good $(\star)$ in upland areas distant of emission sources.

\section{DISCUSSION}

Tissue $\mathrm{N}$ concentrations in moss and lichen were highest in urban sites in Vancouver and Victoria, and in the Lower Fraser Valley. The two main N sources are $\mathrm{NO}_{\mathrm{x}}$ emissions from fossil fuel combustion in the urban areas and $\mathrm{NH}_{3}$ from agricultural sources, including livestock production and manure spreading in the Lower Fraser Valley. A 2005 emissions inventory of the Lower Fraser Valley estimated release of 61,000 tonnes of $\mathrm{NO}_{\mathrm{x}}$, with the major sources being heavy duty vehicles 


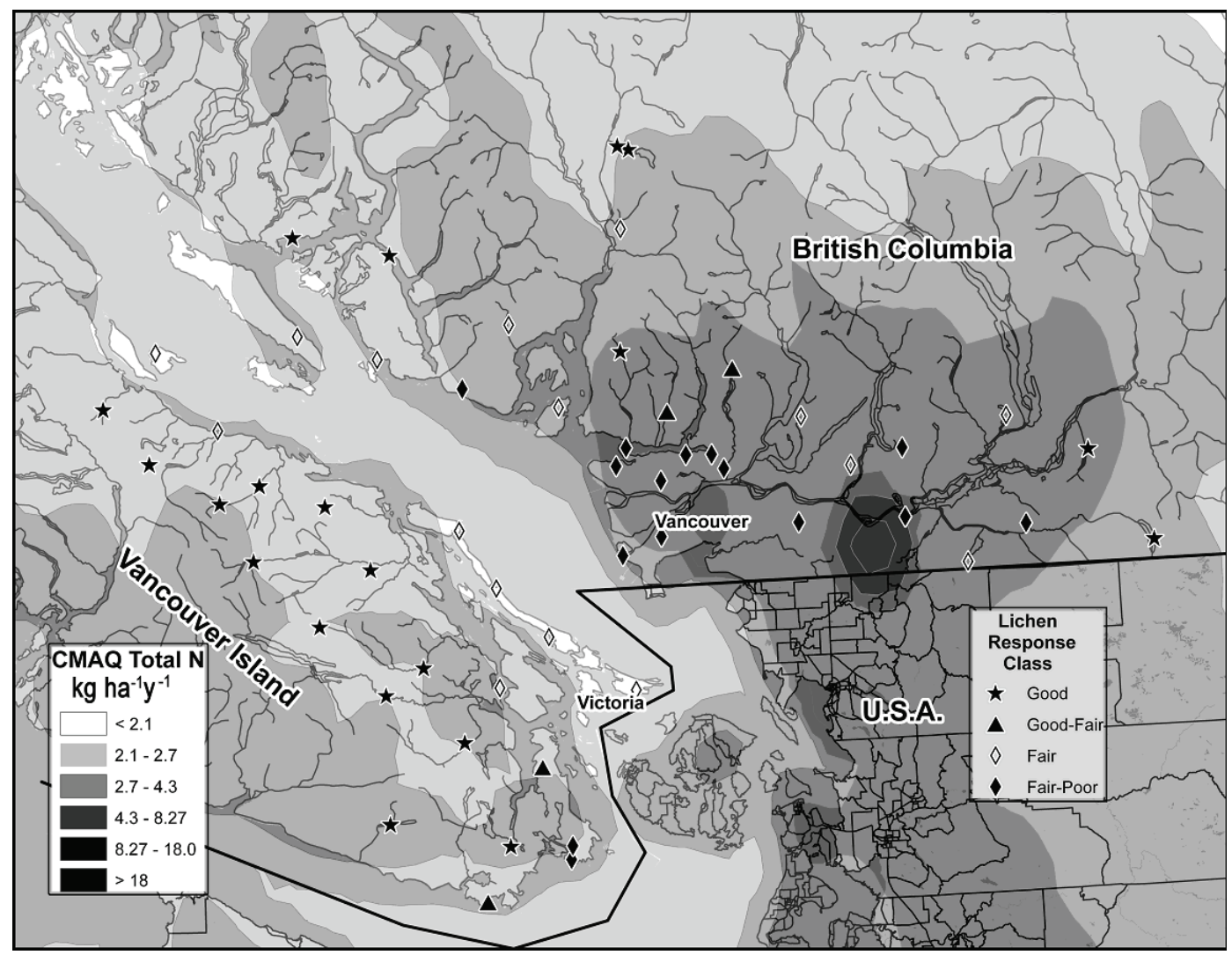

Fig. 5. Spatial distribution of lichen (Platismatia glauca) tissue nitrogen content in Glavich \& Geiser (2008) lichen community structure response classes in southwestern BC. Sites with $\star$ are 'good', meaning all lichen species would be expected to be found; sites with $\diamond$ and $\boldsymbol{\Delta}$ are intermediate and would have lost the most sensitive lichen species and those marked with $\bullet$ are 'poor', meaning that all but the most pollution-tolerant species would have been lost.

(11\%), light duty vehicles (24\%) and marine (14\%), of which $72 \%$ of total originated from Metro Vancouver (MetroVancouver 2007). The same emission inventory reported that there was approximately 18,500 tonnes of $\mathrm{NH}_{3}$ released in this area, with agricultural activities accounting for $76 \%$ of the total. Ammonia emissions are projected to increase to about 23,000 tonnes by 2030 .

The main sources of S to the study area are the combustion of S-rich oils and gasoline (Rhoades 1999), so finding higher tissue concentrations in urban areas would be expected. Sulphur was also found at higher concentrations at low-elevation sites near the Strait of Georgia, likely reflecting the influence of emissions from marine shipping traffic and some contribution from dimethyl sulphide (DMS), naturally generated marine sulphates. In 2005, marine shipping traffic contributed $47 \%$ of the estimated 10,300 tonnes of $\mathrm{SO}_{2}$ emitted to the regional airshed (MetroVancouver 2007). Both $\mathrm{N}$, in the form of $\mathrm{NO}_{\mathrm{x}}$, and $\mathrm{SO}_{2}$ are released principally from combustion sources, which was reflected in the high correlation between the two in analyses of lichen and moss tissues.

Lichen tissue chemistry has been an important component of the air quality work being conducted in the Pacific coastal states (Furbish et al. 2000; Dillman et al. 2007; Geiser \& Neitlich 2007; Glavich \& Geiser 2008).
The work presented here extends this approach into south-western British Columbia. The combination of rain chemistry/tissue calibration coupled with a tissue chemistry survey was successful in elucidating regional spatial patterns of $\mathrm{N}$ and $\mathrm{S}$ deposition, and will provide a base for future work. The beneficial effect of activities directed at reducing $\mathrm{S}$ releases, such as designation of a western Canada Emission Control Area for marine traffic or industrial emission reductions may be reflected in lichen and moss tissues.

The effort to develop relationships which might be used to estimate $\mathrm{N}$ or $\mathrm{S}$ loading based on tissue chemistry clearly fell short of the expectations. A number of factors may be contributing, not the least of which is the small number of sites where precipitation chemistry was available. As well, there are other influences affecting tissue chemistry and atmospheric deposition. Halleraker et al. (1998) has emphasized potential influences of morphology and the form of deposition (wet or dry) in determining chemical composition in moss tissues. In another study, (Pitcairn et al. 2006) showed that in moss species, the proportion of wet to dry deposition and, for $\mathrm{N}$, the chemical form whether it be $\mathrm{NH}_{3}, \mathrm{NH}_{4}{ }^{+}$or $\mathrm{NO}_{\mathrm{x}}$ has an influence on the quality of relationships between deposition and tissue chemistry. There were inter-site differences in mean $\mathrm{NH}_{4}{ }^{+}$(Tab. 1), in mean $\mathrm{SO}_{4}{ }^{2-}$ (Tab. 
2), and in wet/dry deposition ratios (Tab. 3), and climate (Tab. 1) which all could contribute to variability overshadowing possible relationships. It would seem that the small number of sites at which the calibration effort was pursued were not sufficient to cover the range of conditions regionally.

In a very local sense, the four species in this work are responding quite similarly to their depositional environment. Clear evidence of this is in the very high interspecies relationships (Tab. 5) for both $\mathrm{S}$ and $\mathrm{N}$ in tissues. In this sense, any or all of the species could be used in measuring spatial patterns of $\mathrm{N}$ and $\mathrm{S}$ deposition in SW British Columbia, provided the same species were sampled throughout. This is not a new result, and is the basis for the utility of moss and lichens in biomonitoring programs worldwide (e.g., Pesch et al. 2008). As such, the evident relationship between $\mathrm{N}$ and $\mathrm{S}$ deposition estimated by the CMAQ modelled fields and lichen and moss tissues (Fig. 4) were encouraging corroboration of the two approaches. Lichen chemistry does offer the distinct advantage in simplicity where there is a need to delineate spatial deposition patterns in the absence of the extensive datasets needed for detailed atmospheric modelling.

Of the lichen species collected in this work, $P$. glauca was clearly the most suitable for broad-scale surveys. The ubiquity of $P$. glauca near the Strait of Georgia area is similar to that found by Geiser \& Neitlich (2007) where this species was found at more than $96 \%$ of western coastal forest sites, and $85 \%$ of over 1500 plots in the coastal Pacific Northwest. Isothecium was nearly as frequently collected in this study, and could as well be valuable in any subsequent monitoring work. Use of $P$. glauca for potential future work has the significant advantage of the extensive tissue chemistry data assembled by US Forest Service researchers in Washington and Oregon States (USDA 2009), which is not presently available for the moss species.

Thresholds of $\mathrm{N}$ levels in lichens have been developed by relating the tissue $\mathrm{N}$ to related changes in lichen community composition (Geiser \& Neitlich 2007; Fenn et al. 2008). Where $\mathrm{N}$ loading data are available, these response thresholds could perhaps be transformed to critical levels to protect lichen communities. Using a evolving protocol outlined in Glavich \& Geiser (2008), the authors suggested a $\mathrm{N}$ threshold level in Platismatia glauca tissues of $0.54-0.61 \%$, above which are seen varying degrees of degradation in the lichen community. Mapping these proposed levels on the measured $\mathrm{N}$ content in P. glauca from southwest BC serves to highlight areas where lichen communities are under air quality stress (Fig. 6). The excess $\mathrm{N}$ and elevated tissue $\mathrm{N}$ in the Fraser Valley is clearly evident, declining sharply with distance from agricultural areas and population centres. In the Lower Fraser Valley, $\mathrm{NH}_{3}$ is probably of particular concern to lichens and moss species since levels fre- quently exceed the proposed $1 \mu \mathrm{g} \mathrm{NH} \mathrm{N}^{-3}$ critical level recently proposed by Cape et al. (2009) for protection of lichen species. The close match between the modelled CMAQ $\mathrm{N}$ deposition estimates and the tissue $\mathrm{N}$ critical load classes provides support for the utility of the lichen $\mathrm{N}$ classes in assessing environmental $\mathrm{N}$ loadings. Further exploration and development of regional lichen response levels will necessitate northward expansion of the lichen community monitoring work being pioneered in the Northwest states (Geiser 2004).

\section{CONCLUSIONS}

The effort to derive relationships between wet and dry deposition estimates and $\mathrm{N}$ and $\mathrm{S}$ content in three lichen (Platismatia glauca, Hypogymnia physodes, and Parmelia sulcata) and one moss species (Isothecium myosuroides) was unsuccessful. Other components of the work demonstrated the utility of lichen and moss tissue chemistry in elucidating $\mathrm{S}$ and $\mathrm{N}$ depositional patterns in the region, either as independent observations or in comparison with depositional fields derived from atmospheric modelling. Comparing the results with proposed tissue thresholds suggest clearly that lichen communities in low-elevation areas near major population centres and eastward into the Fraser Valley are under N stress.

Future directions for lichen and moss biomonitoring in British Columbia should follow the lead of US Forest Service activities, particularly with respect to expansion and implementation of lichen community monitoring. Precipitation and air chemistry measurements need to be established at other sites in the region to both provide current empirical deposition estimates . As well, additional lichen and moss grid sites need to be sampled for better spatial coverage of southwestern British Columbia, with particular emphasis on areas such as western Vancouver Island which are affected by the coastal shipping emissions.

\section{ACKNOWLEDGEMENTS}

We are grateful for the assistance from the following people: Linda Geiser, USDA Forest Service and Wayne Belzer, Environment Canada PYR provided advice on the methodology and sampling design; Cris Baldazzi and Ute Pott, Consultants; Cecilia Wong, Environment Canada PYR; and Amanda Denney, Simon Fraser University Co-op student, assisted with the moss and lichen sample collection; Scott Wong and Surjit Nizzar, MetroVancouver; Mark Torgerson, Environment Canada PYR; Al Duban, Poul Christensen, and Dave Lockhart, BC Environment, and Geri Crooks, CAPMoN Saturna, assisted with the rain sampling; University of Minnesota Research Analytical Laboratory; Roxanne Vingarzan and Colin di Cenzo provided access to deposition model results generated at the University of British Columbia; Thomas Nippen calculated summary totals from the volume of CMAQ model output. Funding was provided 
though the Environment Canada Georgia Basin Ecosystem Initiative. Suggestions from reviewers on an earlier draft are greatly appreciated.

\section{REFERENCES}

Baron, J.S. 2006. Hindcasting nitrogen deposition to determine an ecological critical load. Ecol. Appl., 16: 433-439.

Benoit, R., M. Desgagn, P. Pellerin, S. Pellerin, Y. Chartier \& S. Desjardins. 1997. The Canadian $\mathrm{MC}_{2}$ : A semi-Lagrangian, semi-implicit wideband atmospheric model suited for finescale process studies and simulation. Mon. Weath. Rev., 125: 2382-2415.

Berg, T. \& E. Steinnes. 1997a. Recent trends in atmospheric deposition of trace elements in Norway as evident from the 1995 moss survey. Sci. Tot. Environ., 208: 197-206.

Berg, T. 1997b. Use of mosses (Hylocomium splendens and Pleurozium schreberi) as biomonitors of heavy metal deposition: From relative to absolute deposition values. Environ. Pollut., 98: 61-71.

Bergström, A.K. \& M. Jansson. 2006. Atmospheric nitrogen deposition has caused nitrogen enrichment and eutrophication of lakes in the northern hemisphere. Glob. Change Biol., 12: 635-643.

Brodo, I., S.D. Sharnoff \& S. Sharnoff. 2001. Lichens of North America. New Haven, Connecticut: Yale University Press.

Cape, J.N., L.J. van der Eerden, L.J. Sheppard, I.D. Leith \& M.A. Sutton. 2009. Evidence for changing the critical level for ammonia. Environ. Pollut., 157: 1033-1037.

Ceburnis, D., E. Steinnes \& K. Kvietkus. 1999. Estimation of metal uptake efficiencies from precipitation in mosses in Lithuania. Chemosphere, 38: 445-455.

Conti, M.E. \& G. Cecchetti. 2001. Biological monitoring: lichens as bioindicators of air pollution assessment - a review. Environ. Pollut., 114: 471-492.

Dillman, K., L.H. Geiser \& G. Brenner. 2007. Air quality biomonitoring with lichens: US Dept. of Agriculture-Forest Service, Alaska Region. Tongass National Forest Report: 323 pp.

Fenn, M.E., J.S. Baron, E.B. Allen, H.M. Rueth, K.R. Nydick, L. Geiser, W.D. Bowman, J.O. Sickman, T. Meixner, D.W. Johnson \& P.N. Neitlich. 2003. Ecological effects of nitrogen deposition in the western United States. Bioscience, 53: 404-420.

Fenn, M.E., S. Jovan, F. Yuan, L. Geiser, T. Meisner \& B.S. Gimeno. 2008. Empirical and simulated critical loads for nitrogen deposition in California mixed conifer forests. Environ. Pollut., 155: 492-511.

Fernández, J.Á., J.R. Aboal, C. Real \& A. Carballeira. 2007. A new moss biomonitoring method for detecting sources of small scale pollution. Atmos. Environ., 41: 2098-2110.

Furbish, C.E., L. Geiser \& C. Rector. 2000. Lichen-air quality pilot study for Klondike Gold Rush National Historical Park and the City of Skagway, Alaska. US Dept of the Interior-National Park Service, Klondike Gold Rush National Historical Park Natural Resources Management Program Report: 47 pp.

Galloway, J.N., J.D. Aber, J.W. Erisman, S.P. Seitzinger, R.W. Howarth, E.B. Cowling \& B.J. Cosby. 2003. The nitrogen cascade. Bioscience, 53: 341-356.

Geiser, L.H. 2004. Manual for monitoring air quality using lichens on national forests of the Pacific Northwest. In: Pacific Northwest Region Air Resource Management Technical Paper: US Dept. of Agriculture-Forest Service: $126 \mathrm{pp}$.

Geiser, L.H. \& P.N. Neitlich. 2007. Air pollution and climate gradients in western Oregon and Washington indicated by epiphytic macrolichens. Environ. Pollut., 145: 203-218.

Glavich, D.A. \& L.H. Geiser. 2008. Potential approaches to developing lichen-based critical loads and levels for nitro- gen, sulfur and metal-containing atmospheric pollutants in North America. The Bryologist, 111: 638-649.

Halleraker, J.H., C. Reimann, P. de Caritat, T.E. Finne, G. Kashulina, H. Niskaavaara \& I. Bogatyrev. 1998. Reliability of moss (Hylocomium splendens and Pleurozium schreberi) as a bioindicator of atmospheric chemistry in the Barents region: Interspecies and field duplicate variability. Sci. Tot. Environ., 218: 123-139.

Hay, J., B. Raymond \& R. Vingarzan. 2005. Dry and wet atmospheric deposition at six sites in the Georgia Basin: Environment Canada Internal Report: (unpublished).

Holdren, J., T.C. Strickland, B.J. Cosby, D. Marmorek, D. Bernard, R. Santore, C.T. Driscoll, L. Pardo, C. Hunsaker \& R.S. Turner. 1993. A national critical loads framework for atmospheric deposition effects assessment. IV. Model selection, application, and critical loads mapping. Environ. Manage., 17: 355-363.

Holoubek, I., P. Korínek, Z. Seda, E. Schneiderová, I. Holoubková, A. Pacl, J. Tríska, P. Cudlín \& J. Cáslavský. 2000. The use of mosses and pine needles to detect persistent organic pollutants at local and regional scales. Environ. Pollut., 109: 283-292.

Ireland, R.R., G.R. Brassard, W.B. Schofield \& D.H. Vitt. 1987. Checklist of mosses of Canada II. Lindbergia, 13: 1-62.

Jeffries, D.S., D.C.L. Lam, M.D. Moran \& I. Wong. 1999. The effect of $\mathrm{SO}_{2}$ emission controls on critical load exceedances for lakes in southeastern Canada. Wat. Sci. Technol., 39: 165-171.

Krupa, S.V. 2003. Effects of atmospheric ammonia $\left(\mathrm{NH}_{3}\right)$ on terrestrial vegetation: a review. Environ. Pollut., 124: 179-221.

Matson, P., K.A. Lohse \& S.J. Hall. 2002. The globalization of nitrogen deposition: consequences for terrestrial ecosystems. Ambio, 31: 113-119.

MetroVancouver. 2007. 2005. Lower Fraser Valley air emissions inventory and forecast and backcast. Vancouver, BC.[OnlineURL:www.metrovancouver.org/about/publication s/Publications/2005 LFV Emissions.pdf].

MetroVancouver. 2008. $200 \overline{7}$ Lower Fraser Valley Air Quality Report: $52 \mathrm{pp}$

Nasr, M., M. Castonguay, J. Ogilve, B.A. Raymond \& P.A. Arp. 2010. Modelling and mapping critical loads and exceedances for the Georgia Basin, British Columbia, using a zero base-cation depletion criterion. J. Limnol., 69(Suppl. 1): 181-192. DOI: 10.3274/JL10-69-S1-18.

Pesch, R., W. Schröder, G. Schmidt \& L. Genssler. 2008. Monitoring nitrogen accumulation in mosses in central European forests. Environ. Pollut., 155: 528-536.

Pfeiffer, H.N. \& P. Barclay-Estrup. 1992. Use of a single lichen species, Hypogymnia physodes, as an indicator of air quality in Northwestern Ontario. Bryologist, 95: 38-41.

Pitcairn, C., D. Fowler, I. Leith, L. Sheppard, S. Tang, M. Sutton \& D. Famulari. 2006. Diagnostic indicators of elevated nitrogen deposition. Environ. Pollut., 144: 941-950.

Porter, E. \& S. Johnson. 2007. Translating science into policy: Using ecosystem thresholds to protect resources in Rocky Mountain National Park. Environ. Pollut., 149: 268-280.

Pott, U. \& D.H. Turpin. 1996. Changes in atmospheric trace element deposition in the Fraser Valley, B.C., Canada from 1960 to 1993 measured by moss monitoring with Isothecium stoloniferum. Can. J. Bot., 74: 1345-1353.

Pott, U. 1998. Assessment of atmospheric heavy metals by moss monitoring with Isothecium stoloniferum Brid. in the Fraser Valley, B.C., Canada. Water Air Soil Pollut., 101: 25-44.

Rabalais, N.N. 2002. Nitrogen in aquatic ecosystems. Ambio, 31: $102-212$

Raymond, B.A. \& U. Pott. 2003. Atmospheric contaminants in biota of forested watersheds near Vancouver, BC: Environment Canada. Georgia Basin Ecosystem Initiative.

Rhoades, F.M. 1999. A review of lichen and bryophyte elemental content literature with reference to Pacific North- 
west species. USDA Forest Service, Pacific Northwest Region: 128 pp.

Ruhling, A. \& G. Tyler. 1969. Ecology of heavy metals-A regional and historical study. Bot. Notiser, 122: 248-259.

Schofield, W.B. 1992. Some common mosses of British Columbia. $2^{\text {nd }}$ Edition. Royal British Columbia Museum, Victoria, BC: 394 pp.

Sirois, A. \& R. Vet. 1999. The precision of precipitation chemistry measurements in the Canadian Air and Precipitation Monitoring Network (CAPMoN). Environ. Monit. Assess., 57: 301-329.

USDA. 2009. National Lichens \& Air Quality database and clearinghouse: provisional element analysis thresholds. [Online URL: gis.nacse.org/lichenair/index.php?page= cleansite].
Vingarzan, R. \& S.M. Li. 2006. The Pacific 2001 Air Quality Study - synthesis of findings and policy implications. Atmos. Environ., 40: 2637-2649.

Wiens, J.H. 1987. Sensitivity of western and northern Canada soils and geology to acidic input. Victoria, B.C.: Technical Committee for the Long-Range Transport of Atmospheric Pollutants in Western and Northern Canada., Coordinating Committee on Soil and Geology Sensitivity Mapping (Canada).

Zhang, L. \& J.R. Brook. 2001. The effect of subgrid velocity scale on site-specific/subgrid area and grid-averaged dry deposition velocities. Atmos. Environ., 35: 3841-3850.

Zhang, L., J.R. Brook \& R. Vet. 2003. A revised parameterization for gaseous dry deposition in air-quality models. Atmos. Chem. Phys., 3: 2067-2082. 